\title{
Determinants of Acute Respiratory Infections Incidence in Children Under Five in the Working Area of the Siak Hulu II Community Health Center in Kampar Regency
}

\author{
Agus Alamsyah*, Tri Kurniya, Ikhtiyaruddin Ikhtiyaruddin, Zulmeliza Rasyid, Yuyun Priwahyuni, Cristine Vita \\ Department of Public Health Sciences, STIKes Hang Tuah, Pekanbaru, Indonesia
}

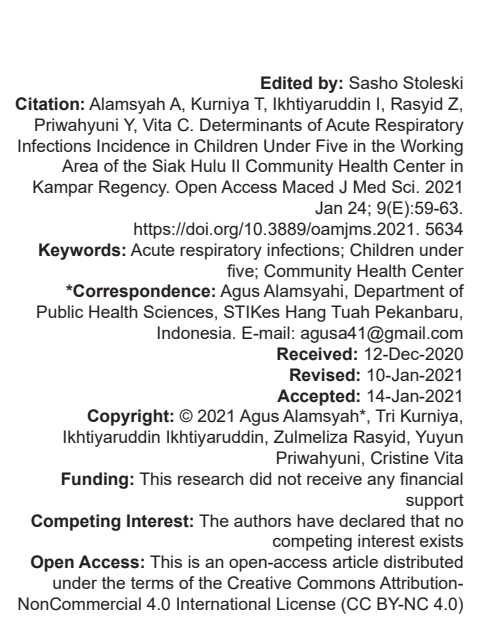

\begin{abstract}
BACKGROUND: The incidence of acute respiratory infections (ARIs) is high among under-five children, especially in developing countries. ARIs are a leading cause of morbidity and mortality in under-five children worldwide. ARIs in children take a heavy toll on life. ARI disease ranks first in the spread of illness in the Siak Hulu II Public Health.

AIM: This study aims to determine the incidence of non-pneumonia ARI in children under five in the working area of the UPTD Siak Hulu II.

METHODS: This research uses quantitative methods with a cross-sectional approach. The sample in this study was 74 children under five aged 12-59 months using the consecutive sampling technique. Data analysis used Chisquare, univariate and bivariate statistical tests.

RESULTS: The results showed that there was a relationship between birth weight $p=0.017$ and $O R=4.844$ cigarette smoke exposure $p=0.012$, indiscriminate snacking $p=0.013$, maternal knowledge $p=0.016$, and exclusive breastfeeding $p=0.038$, with the incidence of non-pneumonia ARI in toddlers aged 12-59 months in the working area of the Siak Hulu II Health Center, Siak Hulu District, Kampar Regency. Respondents who have low birth weight have a 4.8 times greater risk of suffering from ARI.

CONCLUSION: There is a relationship between birth weight, exposure to cigarette smoke, casual snacks, knowledge of mothers, and exclusive breastfeeding with the incidence of ARI in children under five in the work area of the UPTD Siak Hulu II Community Health Center, Siak Hulu District, Kampar Regency.
\end{abstract}

\section{Introduction}

Acute respiratory infections (ARIs) in children are a significant public health problem, especially in developing countries. As per the World Health Organization estimates, ARI causes 3.9 million deaths worldwide each year [1]. Acute respiratory tract infection (ARI) remains a significant public health problem that is widely recognized as the leading cause of mortality and morbidity in children under five [2]. Globally, onefifth of deaths among children under five are due to ARI, primarily pneumonia, which accounts for $18 \%$ of all under-five deaths in particular [3], [4]. ARI continues to be the single largest contributor to morbidity among children and is responsible for approximately $70 \%$ of under-five morbidity in developing countries [5]. About 3.5\% of the global disease burden is caused by ARIs [6]. ARI always ranks first in the group of infants and toddlers in Indonesia. The mortality rate among this group of children in this country is around $33 / 1000$ live births [7]. Underfive mortality due to pneumonia remains higher than child mortality caused by other preventable infectious diseases [8]. Besides, ARI is also often in the first position on the list of 10 most infections in hospitals and health centers 2. Based on data from the Riau Province Health Profile (2018), the number of toddlers suffering from ARI is $43.9 \%$ with patients with ARI pneumonia by $0.79 \%$ and cough not pneumonia by $24.8 \%$ [9]. Based on data from the Kampar District Health Office in 2016, ISPA ranks first in the most extensive disease in Kampar district with $13,413(0.17 \%)$ people, and in 2017 , ARI cases increased to $59,576(0.75 \%)$ cases. In 2018 , there were $24,929(0.29 \%)$ cases of ARI [10]. ISPA disease ranks first in the spread of illness in the Siak Hulu II Public Health Center. In 2018, the proportion of ARI cases in children under five was 1079 (26.8\%) cases [11]. Based on this background, this study aims to analyze the proportions and determinants (factors) associated with the incidence of ARI in children under five in the UPTD working area of Siak Hulu II Public Health Center, Siak Hulu District, Kampar Regency.

\section{Methods}

This study used a quantitative analytic approach that was observational with a cross-sectional 
study design. The research location is in the working area of the Siak Hulu II Community Health Center, Siak Hulu District, Kampar Regency, from March to August. The study population was all mothers who have children under five aged 12-59 months who are in the working area of the UPTD Siak Hulu II Community Health Center. Of the 4016 population, 74 samples were taken using the consecutive sampling technique. The dependent variable of the study was the incidence of non-pneumonia ARI in children under five. Discernment between under five with $A R I$ and not $A R I$ was done by tracing medical record data and interviews with respondents.

There are five independent research variables, namely, low birth weight (LBW) known through interviews and tracing medical record data. It was recorded as LBW if birth weight $<2500 \mathrm{~g}$ and not LBW If $\geq 2500 \mathrm{~g}$. The second independent variable is exposure to cigarette smoke, which means whether or not under five are exposed to cigarette smoke both at home and outside the home is known through interviews. The third independent variable is indiscriminate snacking, namely, the behavior of children under five who like to snack on and parents who want to provide snacks outside without seeing whether the snacks are hygienic and suitable for consumption by toddlers which is known from the interview.

The fourth variable is the mother's knowledge, which is everything that the mother knows about the causes and prevention of ARI in children under five. It is categorized as high knowledge if the respondent can answer the questions correctly $\geq a t$ $60 \%$ and common knowledge if the answer is correct $<60 \%$. The fifth independent variable is exclusive breastfeeding, which is breast milk given when the toddler is $0-6$ months of age without providing any additional food or drink other than breast milk. In this study, the validity and reliability of the questionnaire were tested. Univariate and bivariate data analysis used the Chi-square test.

\section{Results}

\section{Univariate analysis}

The results of the research on the frequency distribution of respondents based on birth weight, exposure to cigarette smoke, indiscriminate snacks, maternal knowledge, and exclusive breastfeeding are shown in Table 1.

Based on Table 1, it can be seen that as many as 74 respondents, there were $39(52.7 \%)$ who did not suffer from ARI, respondents who had children under five with birth weight $<2500 \mathrm{~g}$ were $53(71.6 \%)$ children under five. Respondents who had children
Table 1: Frequency distribution of respondents based on birth weight, exposure to cigarette smoke, casual snacks, knowledge of mothers, and exclusive breastfeeding

\begin{tabular}{lll}
\hline Univariate analysis & Amount & $\%$ \\
\hline ISPA accident & & \\
$\quad$ Yes & 35 & 47.3 \\
$\quad$ No & 39 & 52.7 \\
Birth weight & 53 & \\
$\quad<2500 \mathrm{~g}$ & 21 & 71.6 \\
$\quad 22500 \mathrm{~g}$ & 52 & 28.4 \\
Exposure to cigarette smoke & 52 & 70.3 \\
$\quad$ Exposed not exposed & 22 & 29.3 \\
$\quad$ Casual snacks & 45 & 60.8 \\
$\quad$ Yes & 29 & 39.2 \\
$\quad$ No & 50 & 67.6 \\
Mother knowledge & 24 & 32.4 \\
$\quad$ Low & & \\
$\quad$ High & & 73.0 \\
Exclusive breast milk & 54 & 27.0 \\
$\quad$ No exclusive breast milk & 24 & \\
$\quad$ Exclusive breast milk & &
\end{tabular}

under five who were exposed to cigarette smoke were $52(70.3 \%)$. Of the 74 respondents who have children under five, there are $45(60.8 \%)$ who snack carelessly. Respondents who have insufficient knowledge are 50 $(67.6 \%)$. Respondents who have children under five who are not exclusively breastfed are 54 (73.0\%). In the recording of public opinion research reports at the Community Health Center, there is often confusion between common ARIs and non-pneumonia ARIs. According to the Guidelines for the Control of Acute Respiratory Tract Infection (ISPA), the diagnosis of nonpneumonia ARI includes common colds, pharyngitis, tonsillitis, and otitis [12].

\section{Bivariate analysis}

The results of the study were the relationship between birth weight and the incidence of nonpneumonia ARI in Siak Hulu II Public Health Center, Siak Hulu District, Kampar Regency.

Based on Table 2, it can be seen that of the 55 respondents who have LBW as many as 31 (56.4\%) are respondents with the incidence of $A R I$, and of the 19 respondents who have average birth weight (not LBW) as many as $4(21.1 \%)$ are respondents with ARI incidence. The results of the Chi-square test obtained $p=0.017(<0.05)$, which means that there is a significant relationship between birth weight and the incidence of $A R I$ in children under five.

Table 2: Relationship between birth weight and the incidence of non-pneumonia ARI

\begin{tabular}{|c|c|c|c|c|c|c|c|c|}
\hline \multirow[t]{3}{*}{ Birth weight } & \multicolumn{6}{|c|}{ ISPA accident } & \multirow{2}{*}{\multicolumn{2}{|c|}{ p-value $\quad$ OR $(95 \% \mathrm{Cl})$}} \\
\hline & \multicolumn{2}{|c|}{ ISPA } & \multicolumn{2}{|c|}{ No ISPA } & \multicolumn{2}{|c|}{ Total } & & \\
\hline & $\mathrm{n}$ & $\%$ & $\mathrm{n}$ & $\%$ & $\mathrm{n}$ & $\%$ & & \\
\hline BBLR & 31 & 56.4 & 24 & 43.6 & 55 & 100 & 0.017 & $4.844(1.423-16.488)$ \\
\hline No BBLR & 4 & 21.1 & 15 & 78.9 & 19 & 100 & & \\
\hline Total & 35 & 47.3 & 39 & 52.7 & 74 & 100 & & \\
\hline
\end{tabular}

Based on Table 3, it can be seen that of the 52 respondents who were exposed to cigarette smoke as many as $30(57.7 \%)$ are with the incidence of ARI. Of the 22 respondents who were not exposed to cigarette smoke, $5(22.7 \%)$ had a non-pneumonia incidence of ARI. The results of the Chi-square test obtained $p$ 
$=0.012(<0.05)$, meaning that there is a significant relationship between exposure to cigarette smoke and the incidence of non-pneumonia ARD in children under five.

Table 3: Relationship between exposure to cigarette smoke and the incidence of non-pneumonia ARI

\begin{tabular}{|c|c|c|c|c|c|c|c|c|}
\hline \multirow{3}{*}{$\begin{array}{l}\text { Exposure to } \\
\text { cigarette smoke }\end{array}$} & \multicolumn{5}{|c|}{ ISPA accident } & \multirow[t]{3}{*}{$\%$} & \multirow{3}{*}{\multicolumn{2}{|c|}{$\begin{array}{ll}\text { Value } & \text { OR }(95 \% \mathrm{Cl}) \\
\mathrm{p} & \end{array}$}} \\
\hline & \multicolumn{2}{|c|}{ ISPA } & \multicolumn{2}{|c|}{ No ISPA } & \multirow{2}{*}{$\frac{\text { Total }}{\mathrm{n}}$} & & & \\
\hline & $\mathrm{n}$ & $\%$ & $\mathrm{n}$ & $\%$ & & & & \\
\hline Exposure & 30 & 57.7 & 22 & 42.3 & 52 & 100 & 0.012 & 4.636 (1.485-14.48) \\
\hline No exposure & 5 & 22.7 & 17 & 77.3 & 22 & 100 & & \\
\hline Total & 35 & 47.3 & 39 & 5.7 & 74 & 100 & & \\
\hline
\end{tabular}

Based on Table 4, it can be seen that the 45 respondents who snack carelessly are $29(58 \%)$ with the incidence of ARI. Of the 29 respondents who did not snack carelessly as many as $6(25.6 \%)$ are with the incidence of ARI. The results of the Chi-square test obtained $p=0.013(<0.05)$, which means that there is a significant relationship between indiscriminate snacking and the incidence of $A R I$ in children under five.

Table 4: Relationship between casual snacks and the incidence of non-pneumonia ARI

\begin{tabular}{|c|c|c|c|c|c|c|c|c|}
\hline \multirow[t]{3}{*}{ Casual snack } & \multicolumn{6}{|c|}{ Accident ISPA } & \multirow[t]{3}{*}{ Value $p$} & \multirow[t]{3}{*}{ OR (95\% Cl) } \\
\hline & \multicolumn{2}{|c|}{ ISPA } & \multicolumn{2}{|c|}{ No ISPA } & \multicolumn{2}{|c|}{ Total } & & \\
\hline & $\mathrm{n}$ & $\%$ & $\mathrm{n}$ & $\%$ & $\mathrm{n}$ & $\%$ & & \\
\hline Yes & 29 & 58.0 & 21 & 42.0 & 45 & 100 & 0.013 & $3.938(1.432-10.804)$ \\
\hline No & 6 & 25.6 & 18 & 75.0 & 29 & 100 & & \\
\hline Total & 35 & 47.3 & 39 & 52.7 & 74 & 100 & & \\
\hline
\end{tabular}

Based on Table 5, it is known that of the 50 respondents, $29(57.7 \%)$ had common knowledge with the incidence of ARI. Then from 24 respondents who have high expertise as many as $6(28.6 \%)$ are with the incidence of ARI. The results of the Chi-square test obtained $p=0.016(<0.05)$, which means that there is a significant relationship between maternal knowledge and the incidence of ARI in children under five.

Table 5: Relationship between mother's knowledge and the incidence of non-pneumonia ARI

\begin{tabular}{|c|c|c|c|c|c|c|c|c|}
\hline \multirow[t]{3}{*}{ Mother's knowledge } & \multicolumn{6}{|c|}{ Accident ISPA } & \multirow{3}{*}{\multicolumn{2}{|c|}{ Value $\mathrm{p}$ OR $(95 \% \mathrm{Cl})$}} \\
\hline & \multicolumn{2}{|c|}{ ISPA } & \multicolumn{2}{|c|}{ No ISPA } & \multicolumn{2}{|c|}{ Total } & & \\
\hline & $\mathrm{n}$ & $\%$ & $\mathrm{n}$ & $\%$ & $\mathrm{n}$ & $\%$ & & \\
\hline Loa & 29 & 57.7 & 21 & 42.0 & 50 & 100 & 0.016 & $4.143(1.405-12.214)$ \\
\hline High & 6 & 28.6 & 18 & 75.0 & 24 & 100 & & \\
\hline Total & 35 & 47.3 & 39 & 52.7 & 74 & 100 & & \\
\hline
\end{tabular}

Based on Table 6 , it is known that 30 respondents $(55.6 \%)$ who did not exclusively breastfeed experienced ARI incidents. Respondents with exclusive breastfeeding were $5(25.0 \%)$ respondents with ARI incidence. The results of the Chi-square test obtained $p=0.038(<0.05)$, which means that there is a significant relationship between exclusive breastfeeding and the incidence of $A R I$ in children under five.

Table 6: Relationship between exclusive breastfeeding and the incidence of non-pneumonia ARI

\begin{tabular}{|c|c|c|c|c|c|c|c|c|}
\hline \multirow{3}{*}{ Exclusive birth weight } & \multicolumn{6}{|c|}{ Accident ISPA } & \multirow{3}{*}{\multicolumn{2}{|c|}{$\begin{array}{l}\text { Value } \text { OR }(95 \% \mathrm{Cl}) \\
\mathrm{p}\end{array}$}} \\
\hline & \multicolumn{2}{|c|}{ ISPA } & \multicolumn{2}{|c|}{ No ISPA } & \multicolumn{2}{|c|}{ Total } & & \\
\hline & $\mathrm{n}$ & $\%$ & $\mathrm{n}$ & $\%$ & $\mathrm{n}$ & $\%$ & & \\
\hline No exclusive breast milk & 30 & 55.6 & 24 & 44.4 & 54 & 100 & 0.038 & $3.750(1.193-11.792)$ \\
\hline Exclusive breast milk & 5 & 25.0 & 15 & 75.0 & 20 & 100 & & \\
\hline Total & 35 & 47.3 & 39 & 52.7 & 74 & 100 & & \\
\hline
\end{tabular}

\section{Discussion}

ARI is an important public health problem among children under five. The incidence of ARI in children under five is relatively high, especially in developing countries, one of which is Indonesia. The results of this study indicate that there is a relationship between birth weight and the incidence of nonpneumonia in children under five at the Siak Hulu II Public Health Center, Siak Hulu District, Kampar District. Children under five with LBW have a 4.8 times greater risk of suffering from non-pneumonia ARI compared to children under five who have average birth weight (not LBW). Pregnant women should eat nutritious food, eat fruit and vegetables, healthy food, and vitamin intake to prevent the occurrence of LBW at birth because it can put children under five at risk of ARI and other infections. Malnutrition in children has the potential to increase the risk of ARI during the first 2 years of life (Mwiru, 2013). Other factors that are positively related to ARI are male gender, LBW, working mothers, and high-risk indoor environment [4]. The results of the study also showed that there was a relationship between exposure to cigarette smoke and the incidence of non-pneumonia in children under five at the Siak Hulu II Public Health Center, Siak Hulu District, Kampar District. Children under five who are exposed to cigarette smoke have a 4.6 times greater risk of suffering from non-pneumonia ARI compared to children under five who are not exposed to cigarette smoke. Cigarettes have a very harmful effect on smokers or second-hand smoke, especially toddlers who are accidentally exposed to cigarette smoke. The impact of postpartum tobacco smoke exposure may also be enormous, leading to poorer respiratory health [13]. Environmental tobacco smoke exposure is a recognized risk factor for acute and chronic respiratory disease [14]. Ecological factors and housing standards play a significant role in the transmission of ARI to children. ARI problems are more common in urban areas, especially slum areas than in rural areas [15]. The results of this study indicate that there is a relationship between snacks and the incidence of non-pneumonia ARI in children under five at the UPTD Siak Hulu II Public Health Center, Siak Hulu District, Kampar Regency. Children under five who like to snack carelessly have a 3.9 times greater risk of suffering from non-pneumonia ARI compared to children under five who do not want to snack carelessly. Snacking habits are also an inseparable part of children's lives. Snack food in the school environment varies, such as fried, moonlight, and soft drinks. These snacks can pose a risk to health due to contamination and are not hygienic. Malnutrition influences the burden of symptoms associated with ARI [16]. The results showed that there was a relationship between maternal knowledge and the incidence of non-pneumonia ARI in children under five at the Siak Hulu II Public Health Center, Siak Hulu District, Kampar District. Children under five who 
have mothers with insufficient knowledge have a 4.1 times greater risk of suffering from non-pneumonia ARI compared to children under five who have mothers with high experience. Many socioeconomic factors and other factors include children's age, household income, household conditions, parental education, maternal age, and other factors related to ARI [17]. There is a relationship between exclusive breastfeeding and the incidence of non-pneumonia in children under five at the Siak Hulu II Public Health Center, Siak Hulu District, Kampar District. Children of adolescent mothers and malnourished children were also observed to be at higher risk of developing ARI [18]. Children under five who are not exclusively breastfed have a 3.7 times greater risk of suffering from ARI compared to children under five who are solely breastfed.

Based on the researcher's analysis, most children under five did not receive exclusive breastfeeding when they were babies. It is because there are still many mothers in the working area of the Siak Hulu II Community Health Center who do not know the importance of exclusive breastfeeding. For infants 0-6 months, mothers think that breastfeeding alone is not sufficient for nutritional needs. Mothers provide additional food to babies aged $<6$ months; many respondents work outside the home. Then, some mothers think that formula milk is more practical than breast milk even though one of the benefits that can be provided from breastfeeding is very necessary because it can protect babies against an increase in diarrhea, respiratory infections, obesity, bladder infections, ear infections, and so on. Therefore, researchers argue that mothers should give breast milk only without giving food or drink. Preventing ISPA disease in children must be done early. Current efforts should focus on reducing $\mathrm{ARI}$, one of which can be done by evaluating the impact and pneumococcal vaccine in the routine program of strengthening the immunization system [19]. Besides, it can be done improving environmental conditions can help reduce $A R I$ in children under five in the community [20]. Group intervention efforts need to be done to prevent ARI. Community-based interventions focus on improving housing conditions, reducing fuel use, improving adequate and balanced dietary intake, including exclusive breastfeeding for infants, and early treatment for ARI [21]. Interventions such as providing smoke exits and windows in the bedroom can help reduce the burden of ARI [22].

\section{Conclusion}

Based on the results of the study, it can be concluded that the proportion of ARI incidence in the UPTD Siak Hulu II Public Health Center, Siak Hulu District, Kampar Regency, in 2019 was 35 (47.3\%) from 74 respondents. There is a relationship between birth weight, exposure to cigarette smoke, casual snacks, maternal knowledge, and exclusive breastfeeding with the incidence of ARI in children under five in the UPTD working area of Siak Hulu II Public Health Center, Siak Hulu District, Kampar Regency.

\section{References}

1. World Health Organization. Pneumonia: Factsheet. WHO Media Centre: Geneva: World Health Organization; 2013.

2. Adesanya OA, Chiao C. A multilevel analysis of lifestyle variations in symptoms of acute respiratory infection among young children under five in Nigeria. BMC Public Health. 2016;16(1):880. https://doi.org/10.1186/s12889-016-3565-0 PMid:27561945

3. Selvaraj K, Chinnakali P, Majumdar A, Krishnan IS. Acute respiratory infections among under-5 children in India: A situational analysis. J Nat Sci Biol Med. 2014;5(1):15-20. https:// doi.org/10.4103/0976-9668.127275

PMid:24678190

4. Pinzón-Rondón ÁM, Aguilera-Otalvaro P, Zárate-Ardila C, Hoyos-Martínez A. Acute respiratory infection in children from developing nations: A multi-level study. Paediatr Int Child Health 2016;36(2):84-90. https://doi.org/10.1016/j.toxlet.2016.07.636 PMid:25936959

5. Tazinya AA, Halle-Ekane GE, Mbuagbaw LT, Abanda M, Atashili J, Obama MT. Risk factors for acute respiratory infections in children under five years attending the Bamenda Regional Hospital in Cameroon. BMC Pulm Med. 2018;18(1):7. https://doi.org/10.1186/s12890-018-0579-7

PMid:29338717

6. Rudan I, Boschi-Pinto C, Biloglav Z, Mulholland K, Campbell H. Epidemiology and etiology of childhood pneumonia. Bull World Health Organ. 2008;86(5):408-16. https://doi.org/10.2471/ blt.07.048769

PMid:18545744

7. Sutanto A, Gessner BD, Djlantik I, Steinhoff M, Murphy $H$, Nelson $\mathrm{C}$, et al. Acute respiratory illness incidence and death among children under two years of age on Lombok Island, Indonesia. Am J Trop Med Hyg. 2002;66(2):175-9. https://doi. org/10.4269/ajtmh.2002.66.175

PMid:12135290

8. Shibata T, Wilson JL, Watson LM, LeDuc A, Meng C, Ansariadi, et al. Childhood acute respiratory infections and household environment in an Eastern Indonesian urban setting. Int $\mathrm{J}$ Environ Res Public Health. 2014;11(12):12190-203. https://doi. org/10.3390/ijerph111212190 PMid:25429685

9. Dinkes Riau. Profil Dinas kesehatan Provinsi Riau. 2018.

10. Dinkes Kampar. Profil Dinas Kesehatan Kabupaten Kampar. 2018.

11. Puskesmas Siak Hulu II. Profil Puskesmas Siak Hulu 2. 2018.

12. Dewi DA, Arimbawa PE, Jaelani AK. Evaluation of drugs use with who prescribing indicator in kuta primary health. J Endurance. 2018;3(3):483-9. https://doi.org/10.22216/jen.v3i3.3492

13. Pattenden S, Antova T, Neuberger M, Nikiforov B, De Sario M, Grize L, et al. Parental smoking and children's respiratory health: Independent effects of prenatal and postnatal exposure. Tob Control. 2006;15(4):294-301. https://doi.org/10.1136/ tc. 2005.015065 
PMid: 16885578

14. VankerA, GieRP, ZarHJ. The association between environmenta tobacco smoke exposure and childhood respiratory disease: A review. Expert Rev Respir Med. 2017;11(8):661-73. https://doi. org/10.1080/17476348.2017.1338949

PMid:28580865

15. Gupta KB, Walia BN. A longitudinal study of morbidity in children in a rural area of Punjab. Indian J Pediatr. 1980;47(387):297301. https://doi.org/10.1007/bf02831322

PMid:7228229

16. Orimadegun AE, Myer L. Sex-specific prevalence and trends in acute respiratory infection episodes among children less than 5 years in Nigeria. Niger J Clin Pract. 2019;22(11):1590-9. https:// doi.org/10.4103/njcp.njcp_34_19

PMid:31719282

17. Kanungo S, Bhowmik K, Mahapatra T, Mahapatra S, Bhadra UK, Sarkar K. Perceived morbidity, healthcare-seeking behavior and their determinants in a poor-resource setting: Observation from India. PLoS One. 2015;10(5):e0125865. https://doi.org/10.1371/ journal.pone.0125865

PMid:25965382

18. Kilabuko JH, Nakai S. Effects of cooking fuels on acute respiratory infections in children in Tanzania. Int $\mathrm{J}$ Environ Res Public Health. 2007;4(4):283-8. https://doi.org/10.3390/ ijerph200704040003

\section{PMid:18180538}

19. Nelson CM, Sutanto A, Gessner BD, Suradana IG, Steinhoff MC, Arjoso S. Age- and cause-specific childhood mortality in Lombok, Indonesia, as a factor for determining the appropriateness of introducing Haemophilus influenzae type $b$ and pneumococcal vaccines. J Health Popul Nutr. 2000;18(3):131-8.

PMid:11262765

20. Kumar SG, Majumdar A, Kumar V, Naik BN, Selvaraj K, Balajee K. Prevalence of acute respiratory infection among under-five children in urban and rural areas of puducherry, India. J Nat Sci Biol Med. 2015;6(1):3-6. https://doi. org/10.4103/0976-9668.149069

PMid:25810626

21. Keleb A, Sisay T, Alemu K, Ademas A, Lingerew M, Kloos H, et al. Pneumonia remains a leading public health problem among under-five children in peri-urban areas of northeastern Ethiopia. PLoS One. 2020;15(9):e0235818. https://doi. org/10.1371/journal.pone.0235818

PMid:32915807

22. Suguna E, Kumar SG, Roy G. Prevalence and risk factors of acute respiratory infection among school children in coastal South India. J Glob Infect Dis. 2014;6(3):95-8. https://doi. org/10.4103/0974-777x.138498

PMid:25191048 